\title{
THE CONTENT OF MACRO- AND MICROELEMENTS IN THE SHOOTS OF GLYCERIA MAXIMA OF THE SŁUPIA RIVER
}

\author{
Agnieszka Parzych ${ }^{1}$, Małgorzata Cymer ${ }^{2}$ \\ 1 Environmental Chemistry Department, Institute of Biology and Environmental Protection, Pomeranian \\ University, Arciszewskiego 22b St., 76-200 Slupsk, Poland, e-mail: parzycha1@op.pl \\ 2 Department of Land Reclamation and Environmental Management, University of Warmia - Mazury, Plac \\ Łódzki 2, 10-719 Olsztyn, Poland
}

Received: 2014.05.13 Accepted: 2014.08.05 Published: 2014.10.07

\begin{abstract}
The study shows the content of macro- and microelements in the leaves and rhizomes of Glyceria maxima of the Słupia River in Słupsk. The content of macro- and microelements in G. maxima was analyzed for each component separately and in an integrated way, and comparing the demand for nutritions. The largest quantity of nitrogen, phosphorus, potassium, magnesium and calcium were found in the leaves, meanwhile zinc, iron, manganese, nickel and copper in the G. maxima rhizomes. The amount of $\mathrm{Zn}$ and $\mathrm{Cu}$, in all of the tested positions, within the range of the limit for the plants, and the concentrations of $\mathrm{Ni}$ and Mn exceed physiological needs. The U Mann Whitney test showed a number of statistically significant differences in the concentration of the analyzed elements in leaves - rhizomes, leaves - bottom sediment and rhizome - bottom sediment relation. The relations between designated heavy metals formed a following series: $\mathrm{Mn}>\mathrm{Fe}>\mathrm{Zn}>\mathrm{Ni}>\mathrm{Cu}$ in leaves and $\mathrm{Fe}>\mathrm{Mn}>\mathrm{Zn}>\mathrm{Ni}>\mathrm{Cu}$ in rhizomes. The G. maxima shoots accumulated 985.8 do $1441.4 \mathrm{mmol}_{\mathrm{c}} \cdot \mathrm{kg}^{-1}$ in all the analyzed components, and the lower value of the sum of the accumulated macro- and microelements were found in rhizomes. The sum of ion comospition of the macronutrients in the leaves and rhizomes was similar. The content of nitrogen was $51.7-53.7 \%$ of this amount, $5.8-8.6 \%$ phosphorus, potassium $22.8-26.6 \%, 4.9-5.8 \%$ of magnesium, calcium, $8.2-11.9 \%$, and trace elements were $0.58 \%$ in total, in the case of leaves and $8.70 \%$ in the rhizomes.
\end{abstract}

Keywords: macrophytes, macroelements, trace elements, accumulation, pollution.

\section{INTRODUCTION}

The pollution of urban ecosystems with the anthropogenic substances, including heavy metals, significantly affects the increase in the concentration of the macro-and microelements in the bottom sediments and the coastal vegetation of many rivers [Buszewski et al. 2000, Yang et al. 2001, Dąbkowska-Naskręt and Różański 2009]. The macrophytes, which next to the phytoplankton, macrozoobenthos and fish, are one of the basic elements of the assessment of the ecological status of rivers, are used to bioindicate aquatic ecosystems [Skorbiłowicz 2003, Obolewski and Glińska-Lewczuk 2006, Rabajczyk and Jóźwiak
2009]. The state of water reservoirs pollution, with both macro- and microelements, is very well reflected by the aquatic plants [Aksoy et al. 2005, Letachowicz et al. 2006, Sasmaz et al. 2008, Baldantoni et al. 2009, Klink et al. 2013]. Currently, a significant impact on the chemical composition of the bottom sediments has the intensity of catchment area use and sewage inflow [Misztal et al. 1996, Salati and Moore, 2009]. This leads to an increase in the content of many elements in river sediments, which are important part of the water environment. Most of the heavy metals entering the river are connected and transported with the slime, which leads to the rise of sediments [Kruopiene 2007] and may be a second- 
ary source of pollution, which despite the cut-off of primary sources continues to threaten aquatic ecosystems [Grynkiewicz et al. 2006]. Most of the chemical elements accumulated in the river sediments, is bioaccumulated in plant and animal tissue, what causes the increase of the risk of their poisoning within the trophic chain, on the top of which stands a man. The absorption and bioaccumulation of the components needed by the plants results from the physiological needs and is a part of the natural cycle [Kabata-Pendias and Szteke 2005]. The proper functioning of the plants requires basic macroelements ( $, \mathrm{P}, \mathrm{K}, \mathrm{Ca}, \mathrm{Mg}$ ), as well as small amounts of microelements $(\mathrm{Fe}, \mathrm{Zn}$, $\mathrm{Cu}, \mathrm{Ni}, \mathrm{Mn}$ ), that are natural components of the ecosystems [Wolf and Gworek 2009]. However, their excessive concentration in the environment is harmful, because of their sufficiently high concentration interferes with the functioning of the ecosystems, threat to living organisms [GrucaKrólikowska and Wacławek 2006]. Controlling the chemical composition of the coastal vegetation and bottom sediments in urban areas is necessary because it allows the identification of existing and potential risks arising from the toxic effects of heavy metals on the aquatic environment and human health. A good indicator of the quality of bottom sediments is Glyceria maxima (Hartm.) Holmb.), [Rabajczyk and Jóźwiak 2009, Teuchies et al. 2013].

The aim of the study was to compare the ability of accumulation of the above and belowground shoots of the Glyceria maxima nutrients and selected heavy metals. The contents of macro-and microelements in G. maxima were analyzed considering each component separately and in an integrated way - by comparing the demand for nutrients. The study takes into account the effect of the bottom sediments to the tested macrophyt.

\section{MATERIAL AND METHODS}

\section{The study area}

The study was conducted on a section of the Stupia River within the city of Słupsk. The Słupia River is located in the central part of Pomerania (northern Poland). The lowland watercourse is $138,6 \mathrm{~km}$ long and the catchment occupies the area of $620 \mathrm{~km}^{2}$. From the north, the catchment is bordered by the Baltic Sea catchment, from the west by the Wieprza River catchment, from the south by the Brda River catchment, from the east by the of Leba and Lupawa catchment. The sources of the Stupia River are located in the Kashubian Lake District, near Sierakowska Huta, at an altitude of $178 \mathrm{~m}$ above sea level. The width of the riverbed ranges from $7 \mathrm{~m}$ in the upper part of the river to $40 \mathrm{~m}$ at the estuary, where the average flow is $15,5 \mathrm{~m}^{3} \cdot \mathrm{s}^{-1}$. The area of the city of Stupsk includes $8 \mathrm{~km}$ section of the Stupia River with varying degrees of transformation of the riverbed (low, medium or high) [Obolewski 2010], with shores covered with numerous macrophytes (Table 1).

\section{The methodology}

The study was conducted in July 2013, within the 10 stations located throughout the city. Samples of the aboveground (leaves) and belowground (rhizomes) shoots of Glyceria maxima, collected in the river side zone of the Stupia River. Within each of the experimental stations sev-

Table 1. The characteristics of the research stations

\begin{tabular}{|c|c|c|c|c|c|c|}
\hline \multirow{2}{*}{$\begin{array}{c}\text { Research } \\
\text { stations }\end{array}$} & \multirow{2}{*}{$\begin{array}{c}\text { The degree of } \\
\text { the riverbed } \\
\text { transformation }\end{array}$} & \multirow{2}{*}{$\begin{array}{c}\text { Type } \\
\text { ground }\end{array}$} & Glyceriamaxima & Typhalatifolia & Phragmitesaustralis & Phalarisarundinacea \\
\cline { 4 - 6 } & low & mud & + & + & + \\
\hline 1 & low & mud & + & + & + \\
\hline 3 & low & mud & sand & + & + & + \\
\hline 4 & medium & gravel & + & + & + \\
\hline 5 & high & gravel & + & + & + \\
\hline 6 & high & gravel & + & + & + \\
\hline 7 & medium & sand & gravel & + & + \\
\hline 8 & medium & mud & + & + \\
\hline 9 & low & & + & + \\
\hline
\end{tabular}


eral shoots were taken. Then the mixed samples were formed separately from the aboveground and belowground shoots. After transportation to the laboratory the plant material was cleaned from mineral soil portion, rinsed in distilled water and dried to constant weight at $65^{\circ} \mathrm{C}$ and homogenized in a grinder. The total contents of nitrogen was determined by Kiejldahl method, and the phosphorus by the molybdate method, after mineralization in the mixture of concentrated $\mathrm{H}_{2} \mathrm{SO}_{4}$ and $30 \% \mathrm{H}_{2} \mathrm{O}_{2}$. In order to determine the metallic elements, the plant samples were mineralized wet in a closed system, in the mixture of concentrated $\mathrm{HNO}_{3}$ and $30 \% \mathrm{H}_{2} \mathrm{O}_{2}$ (Sobczyński et al. 1996). To the resulting solution, the contents of $\mathrm{K}, \mathrm{Mg}, \mathrm{Ca}, \mathrm{Zn}, \mathrm{Cu}, \mathrm{Ni}, \mathrm{Mn}$, and $\mathrm{Fe}$ by atomic absorption spectrometry (Aanalyst 300, PerkinElmer). The analysis were carried in airacetylene flame of the Ostrowska et al. [1991]. The study used the original standard solutions (Merck KGaA, 1g/1000 ml).

\section{The desription of the results}

In order to characterize and compare the concentration of selected macro- and microelements in the shoots above ground and belowground Glyceria maxima, medium, minimum and maximum values were calculated, standard aberration and coefficient of variation (CV). The distribution of the content of the analyzed elements was tested by the Shapiro-Wilk test. The significance of the differences in the macro- and microelements in the shoots of Glyceria maxima was verified by non-parametric Mann Whitney U test. For the calculations Statistica (7.1) was used. G. maxi- ma's demand for nutrients was described by the ANE (Accumulation Nutrient Elements) method [Ostrowska 1987]. The sum of the components (Y) $\mathrm{mmol}_{\mathrm{c}} \cdot \mathrm{kg}^{-1}$ was calculated from the formula:

$$
Y=\sum_{i=1}^{i}(Z: z)
$$

where: $Z$ - content of the element in $\mathrm{mgkg}^{-1}$, $z$ - atomic weight/ion valency.

After the calculation of Y, the percentage (X) of each element in the sum of:

$$
X=\frac{(Z: z) \cdot \frac{100}{Y}}{Y}
$$

was calculated.

The study contained the effect of the sediments on the tested macrophyt (Table 2).

\section{RESULTS AND DISCUSSION}

The sediments of the Stupia River were characterized by a low content of organic matter and erythrocyte and a slightly alkaline reaction (Table 2). The concentration of most elements in the studied sediments was low and remained within the limits of the geochemical background for most of the analyses [Kabata-Pendias and Pendias 1999]. Only in the case of zinc, copper and nickel the concentration occasionally exceeded the geochemical background for stations in the central part of the city. According to the classification of Lawa [1998] and Wolska and Mędrzycka [2009], the Słupia River sediments were classified as class I, due to the presence of

Table 2. The physical and chemical features of the bottom sediments of the Stupia River

\begin{tabular}{|c|c|c|c|}
\hline Parameter & Average $\pm \mathrm{SD}$ & Minimum - maximum & CV $\%$ \\
\hline Organic matter \% & $2.1 \pm 2.5$ & $7.6-7.9$ & $4.0-8.2$ \\
\hline $\mathrm{pH}\left(\mathrm{H}_{2} \mathrm{O}\right)$ & $7.8 \pm 0.4$ & $6.7-8.1$ & 5.2 \\
\hline $\mathrm{pH}(\mathrm{KCl})$ & $7.7 \pm 0.4$ & $560.0-2030.0$ & 57.6 \\
\hline $\mathrm{N}, \mathrm{mg} \cdot \mathrm{kg}^{-1}$ & $969.5 \pm 558.1$ & $396.2-1197.7$ & 39.6 \\
\hline $\mathrm{P}, \mathrm{mg} \cdot \mathrm{kg}^{-1}$ & $609.9 \pm 241.2$ & $296.3-852.7$ & 37.8 \\
\hline $\mathrm{K}, \mathrm{mg} \cdot \mathrm{kg}^{-1}$ & $506.7 \pm 191.7$ & $316.3-1328.7$ & 36.7 \\
\hline $\mathrm{Mg}, \mathrm{mg} \cdot \mathrm{kg}^{-1}$ & $842.9 \pm 309.7$ & $848.3-5836.7$ & 64.9 \\
\hline $\mathrm{Ca}, \mathrm{mg} \cdot \mathrm{kg}^{-1}$ & $2268.8 \pm 1471.5$ & $12.4-104.7$ & 82.3 \\
\hline $\mathrm{Zn}, \mathrm{mg} \cdot \mathrm{kg}^{-1}$ & $34.1 \pm 28.0$ & $2.6-15.1$ & 52.8 \\
\hline $\mathrm{Cu}, \mathrm{mg} \cdot \mathrm{kg}^{-1}$ & $8.36 \pm 4.4$ & $8.6-16.4$ & 20.8 \\
\hline $\mathrm{Ni}, \mathrm{mg} \cdot \mathrm{kg}^{-1}$ & $11.9 \pm 2.5$ & $58.1-376.7$ & 73.3 \\
\hline $\mathrm{Mn}, \mathrm{mg} \cdot \mathrm{kg}^{-1}$ & $152.1 \pm 111.5$ & $4008.0-15503.3$ & 45.2 \\
\hline $\mathrm{Fe}, \mathrm{mg} \cdot \mathrm{kg}^{-1}$ & $9293.5 \pm 4203.6$ & & \\
\hline
\end{tabular}

$\mathrm{SD}$ - standard deviation, $\mathrm{CV}$ - coefficient of variation. 
heavy metals assayed, as the non-contaminated sediments. The content of the tested components in the sediments of the Stupia River does not affect living organisms (Table 2).

The content of macronutrients in the shoots of Glyceria maxima reflects the supply of nutrients. The largest amount of nitrogen, phosphorus, potassium, magnesium and calcium were in the leafs and the largest amount of zinc, iron, manganese, nickel and copper the G. maxima rhizomes (Figures 1 and 2).

These results are confirmed by the research conducted by Vardanyan and Ingol [2006] and
Klink et al. [2013] on the ecology of aquatic plants. According to Sharma et al. [2006], the higher concentration of macroelements in aboveground shoots is determined by the processes of photosynthesis. The research conducted by Baldontini et al. [2009] also confirm the presence of high concentrations of macroelemnts in above-ground shoots rather than in the belowground water vegetation. The results also indicate that the rhizomes of the G.maxima contain significant amounts of macroelements and are a valuable reservoir of ingredients necessary for their growth and development.
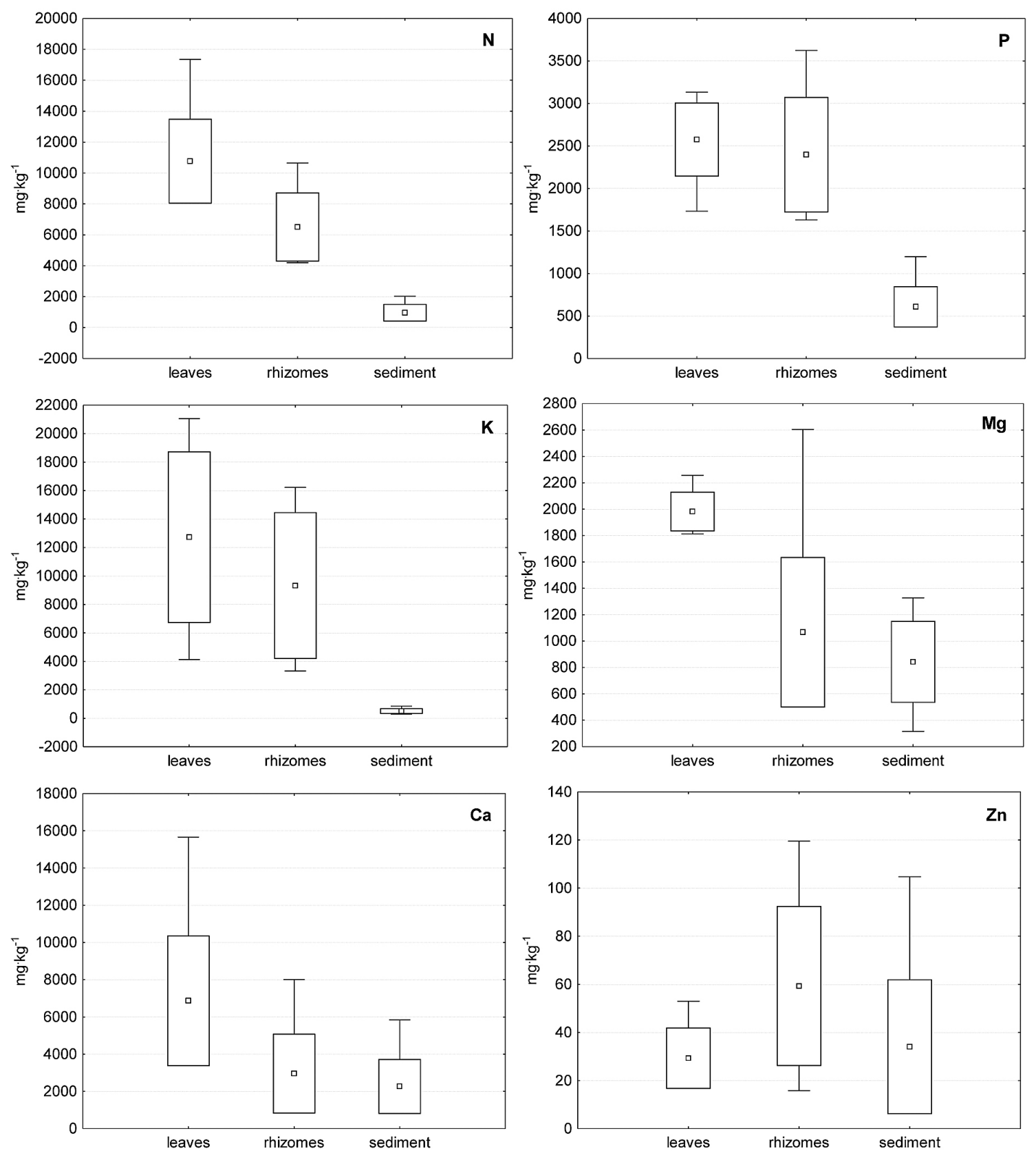

Figure 1. The content of nitrogen, phosphorus, potassium, magnesium, calcium and zinc in the G. maxima sediments and shoots. The dot (average value), rectangle (standard deviation), mustache (minimum-maximum). 

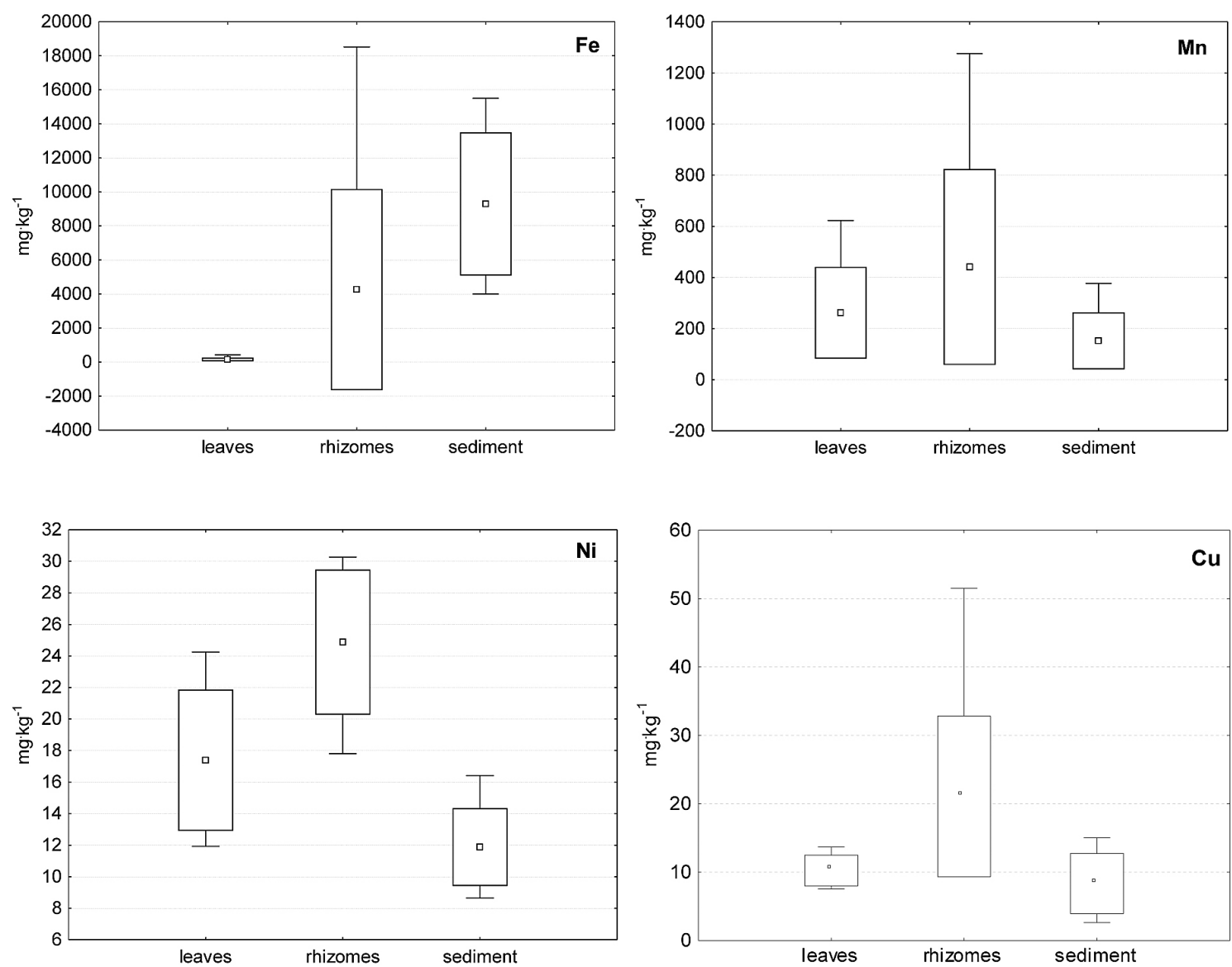

Figure 2. The content of iron, manganese, nickel and copper in the G. maxima sediments and shoots (average value), rectangle (standard deviation), mustache (minimum-maximum)

The content of the heavy metals in the water plants often exceeds its content in the surrounding aqueous environment by a number of times [Sadler 1998, Aksoy et al. 2005]. The wide range of variation in the concentration of the heavy metals is caused by biology and ecology of the individual species. In the case of $\mathrm{Zn}, \mathrm{Fe}, \mathrm{Mn}, \mathrm{Ni}$ and $\mathrm{Cu}$ the content was larger in the belowground stems (rhizomes) than in the aboveground (leaves). Similar relations in the distribution of microelements in the shoots of other macrophytes were shown in the studies by Aksoy et al. [2005], Vardanyan and Ingol [2006] and Klink, et al. [2013]. The levels of zinc and copper in the G.maxima shoots stays in the limit of values for the plants, respectively $\mathrm{Zn}: 10-70 \mathrm{mg} \cdot \mathrm{kg}^{-1}$ and $\mathrm{Cu}$ : 5-20 mg $\mathrm{kg}^{-1}$ (Figure 2) [Kabata-Pendias and Pendias 1999, Ostrowska, Porębska 2002]. In the case of $\mathrm{Mn}$, the increased content was found both in the aboveground and the belowground shoot of the G. maxima. However, at any position manganese level did not exceed the value recognized as toxic $\left(>500 \mathrm{mg} \cdot \mathrm{kg}^{-1}\right)$ [Kabata-Pendias and Pen- dias 1999]. The increased content of $\mathrm{Mn}$ in the shoots, in relation to the physiological demand, indicates a significant share of this macrophyt in the purification of the water and sediments of the Słupia River from manganese compounds available for the plants. Fe content in the leaves of G. maxima was within the range of limit values for the plants $\left(50-250 \mathrm{mg} \cdot \mathrm{kg}^{-1}\right)$, and in the rhizomes it reached a very high level (average $4259.9 \mathrm{mg} \cdot \mathrm{kg}^{-1}$ ), Figure 2. Such a high concentration of iron in the rhizomes may indicate accumulating properties of this species in relation to Fe. At the same time, small concentrations of this element in the leaves indicate a protective barrier that restricts the movement of the iron compounds from below to aboveground shoots. The content of $\mathrm{Ni}$ in both leaves and rhizomes of the G. maxima, exceeded the physiological requirements $\left(0.1-5.0 \mathrm{mg} \cdot \mathrm{kg}^{-1}\right)$ of the most plants, [Kabata-Pendias and Pendias 1999], which indicates the little contamination of the aquatic environment with that element. Nickel is easily taken up by the plants and transported to the aboveg- 
round parts and it's excess is accumulated in the roots [Ostrowska et al. 1991]. In the areas such as agglomerations, it's values are usually higher than the physiological demand, because nickel is easily bioaccumulated especially by the water plants [Sarosiek and Natkaniec-Wożakowska 1993]. The relations between the designated heavy metals are arranged in the following series: $\mathrm{Mn}>\mathrm{Fe}>\mathrm{Zn}>\mathrm{Ni}>\mathrm{Cu}$ and in the leaves $\mathrm{Fe}$ $>\mathrm{Mn}>\mathrm{Zn}>\mathrm{Ni}>\mathrm{Cu}$ in the rhizomes.

The results of the non-parametric Mann Whitney $U$ test showed a number of statistically significant differences in the content of macroand microelements within 10 research stations in the city of Słupsk, in relations: leaves - rhizomes, leaves - bottom sediment and rhizome - bottom sediment (Table 3).
In order to assess the content of macro- and microelements in the Glyceria maxima shoots the ANE (Accumulation Nutrient Elements) method was used [Ostrowska 1987]. The sum of the components reflects the whole so-called nutritional factor. The shoots of G. maxima accumulated from 985.8 to $1441.4 \mathrm{mmol}_{\mathrm{c}} \cdot \mathrm{kg}^{-1}$ of all the analyzed components, and the lower value of the sum of the accumulated macro- and microelements found in the rhizomes (Table 4).

Macronutrients were collected in $61.4 \%$ of the leaves and $38.6 \%$ of the rhizomes. Micronutrients were characterized by a different distribution, $8.9 \%$ was accumulated in the leaves, and $91.1 \%$ in the rhizomes. The composition of the macronutrients in the leaves and rhizomes was similar. The share of nitrogen was $51.7-53.7 \%$

Table 3. The results the Mann-Whitney test - the importance of the diversity of the content of macro- and microelements in the G. maxima leaves and rhizomes and the bottom sediments of the river

\begin{tabular}{|c|c|c|c|}
\hline Elements $\left[\mathrm{mg}^{\mathrm{k}}{ }^{-1}\right]$ & Leaves - rhizomes & Leaves - bottom sediments & Rhizomes - bottom sediments \\
\hline $\mathrm{N}$ & +++ & +++ & +++ \\
\hline $\mathrm{P}$ & - & +++ & ++ \\
\hline $\mathrm{K}$ & - & +++ & - \\
\hline $\mathrm{Mg}$ & ++ & +++ & - \\
\hline $\mathrm{Ca}$ & - & - & - \\
\hline $\mathrm{Zn}$ & - & - & ++ \\
\hline $\mathrm{Cu}$ & +++ & ++ & ++ \\
\hline $\mathrm{Ni}$ & ++ & - & + \\
\hline $\mathrm{Mn}$ & - & +++ & ++ \\
\hline $\mathrm{Fe}$ & ++ & + & + \\
\hline
\end{tabular}

- no differences, + statistically significant differences $\mathrm{p}<0,05,++$ statistically significant differences $\mathrm{p}<0,01$, +++ statistically significant differences $\mathrm{p}<0,001$.

Table 4. The average accumulation of components in the above and belowground shoots of the G. maxima*

\begin{tabular}{|c|c|c|}
\hline \multirow{2}{*}{ Elements } & \multicolumn{2}{|c|}{ Glyceria maxima } \\
\hline & Leaves & Rhizomes \\
\hline$\Sigma$ macro $\left[\mathrm{mmol}_{\mathrm{c}} \cdot \mathrm{kg}^{-1}\right]$ : & 1433 & 900 \\
\hline$\% N$ in $\Sigma$ & 53.7 & 51.7 \\
\hline$\% \mathrm{P}$ in $\Sigma$ & 5.8 & 8.6 \\
\hline$\% \mathrm{~K}$ in $\Sigma$ & 22.8 & 26.6 \\
\hline$\%$ Ca in $\Sigma$ & 11.9 & 8.2 \\
\hline$\% \mathrm{Mg}$ in $\Sigma$ & 5.8 & 4.9 \\
\hline$\Sigma$ mikro $\left[\mathrm{mmol}_{\mathrm{c}} \cdot \mathrm{kg}^{-1}\right]$ : & 8.4 & 85.8 \\
\hline$\% \mathrm{Zn}$ in $\Sigma$ & 5.3 & 1.1 \\
\hline$\% \mathrm{Cu}$ in $\Sigma$ & 1.9 & 0.4 \\
\hline$\% \mathrm{Ni}$ in $\Sigma$ & 3.5 & 0.5 \\
\hline$\% \mathrm{Mn}$ in $\Sigma$ & 56.5 & 9.4 \\
\hline$\% \mathrm{Fe}$ in $\Sigma$ & 32.8 & 88.6 \\
\hline$\Sigma$ macro $+\Sigma$ mikro & 1441.4 & 985.8 \\
\hline
\end{tabular}

* Expressed as the sum of the components and their share in the total. of this amount, 5.8-8.6\% phosphorus, potassium $22.8-26.6 \%, 4.9-5.8 \%$ of magnesium, calcium, $8.2-11.9 \%$, and trace elements were $0.58 \%$ in total in the case of leaves and $8.70 \%$ in the rhizomes.

The similar relations between the measured amount of ingredients in the various plant species were shown by Porębska and Ostrowska [2002] in their study. A large amount of manganese and iron in all of the measured components in the leaves and iron the rhizomes show excessive absorption from the bottom sediments, which favored slightly alkaline reaction of the bottom sediments (Table 2). The G. maxima leaves accumulated more nitrogen, calcium, magnesium, zinc, copper, nickel and manganese, since the rhizomes accumulated more of phosphorus, potassium and iron. 


\section{CONCLUSIONS}

The results indicate that the greatest amount of nitrogen, phosphorus, potassium, magnesium and calcium were in the leaves of Glyceria maxima. The rhizomes also accumulated significant amounts of macroelements so that they can act as a backup body.

The largest amounts of heavy metals were found in belowground stems (rhizomes). The content of zinc and copper at all tested locations ranged within the limit for the plant. The increased content of manganese was shown, both in the leaves and the rhizomes, which indicates a considerable share of the G. maxima in the purification of water and sediment river from the compounds of manganese. Fe content in the leaves maintained at an acceptable level, and in the rhizomes it reached a very high level, which may indicate the accumulating feature of this species relative to $\mathrm{Fe}$. The content of Ni in both the above and belowground $G$. shoots exceeded the physiological need, indicating the little contamination of the aquatic environment of the Stupia River by this element.

The results of the non-parametric Mann Whitney $U$ test showed a number of statistically significant differences in the content of macroand microelements in the relation: leaves - rhizomes, leaves - bottom sediment and rhizome bottom sediment.

Shoots of G.maxima accumulated 985.8 to $1441.4 \mathrm{mmol}_{\mathrm{c}} \cdot \mathrm{kg}^{-1}$ in all analyzed components, where lower value of the accumulated sum of macro- and microelements were found in the rhizomes. The sum of the ionic composition of macronutrients in the leaves and rhizomes were similar. The content of nitrogen was $51.7-53.7 \%$ of this amount, $5.8-8.6 \%$ phosphorus, potassium $22.8-26.6 \%, 4.9-5.8 \%$ of magnesium, calcium, $8.2-11.9 \%$, and trace elements were $0.58 \%$ in the leaves and $8.70 \%$ in the rhizomes.

\section{REFERENCES}

1. Aksoy A., Demirezen D., Duman F. 2005. Bioaccumulation, detection and analyses of heavy metal pollution in Sultan marsh and its environment. Water Air Soil Poll. 164, 241.

2. Baldantonid D., Ligrone R., Alfania A. 2009.Macro- and trace-element concentration in leavesand roots of Phragmitesaustralis in volcanic lake in Southern Italy. J. Geochem. Explor. 101, 166.
3. Buszewski B., Jastrzębska A., Kowalkowski T., Górna-Binkul A., 2000. Monitoring of selected heavy metals uptake by plants and soils in the area of Toruń, Poland. Pol. J. Environ. Stud. 9, 6, 511-515.

4. Dąbkowska-Naskręt H., Różański S. 2009. Formy połączeń $\mathrm{Pb}$ i $\mathrm{Zn}$ w glebach miasta Bydgoszczy, Ochrona Środowiska i Zasobów Naturalnych 41, 489-496.

5. Gruca-Królikowska S., Wacławek W. 2006. Metale w środowisku. Cz. II. Wpływ metali ciężkich na rośliny, Chemia $\cdot$ Dydaktyka $\cdot$ Ekologia $\cdot$ Metrologia $11,1-2,41-56$.

6. Grynkiewicz M., Dembska G., Wisniewski S., Aftanas B. 2006. Ocena jakości osadów dennych pobieranych przy strefie brzegowej Zatoki Gdańskiej, Chem. Inż. Ekol. 13, 284-289.

7. Kabata-Pendias A., Pendias H. 1999. Biogeochemia pierwiastków śladowych, PWN, Warszawa.

8. Kabata-Pendias A., Szteke B. 2005. Pierwiastki śladowe w układzie gleba-roślina, Inż. Ekol. 26, 28-29.

9. Klink A., Wisłocka M., Musiał M., Krawczyk J. 2013. Macro- and trace-elements accumulation in Typhaangustifolia L. and Typhalatifolia L. organs and their use in bioindication, Pol. J. Environ. Stud. 22, 1, 183-190.

10. KruopieneJ., 2007. Distribution of heavy metals in sediments of the Nemunas River (Lithuania). Pol. J. Environ. Stud. 16, 5, 715-722.

11. Lawa, 1998. Landesarbeitsgemeinschaft Wasser: Beurteilung der Wasserbeschaffen-heit von Fließgewässern in der Bundesrepublik Deutschland - chemische Gewässergüteklassifikation, Zielvorgaben zum Schutz oberirdischer binnengewässer Band 2, Berlin.

12. Letachowicz B., Krawczyk J., Klink A., 2006. Accumulation of heavy metals in organs of Typhalalifolia L., Pol. J. Environ. Stud. 15 (2a), 407.

13. Misztal M., Smal H., Ligęza S. 1996.Zawartość wybranych makro- i mikropierwiastków w osadach dennych rzeki Bystrzycy. Zesz. Prob. Post. Nauk Rol. 437, 291-298.

14. Obolewski K. 2010. Ocena jakości wód powierzchniowych na obszarach zurbanizowanych z wykorzystaniem makrobezkręgowców bentosowych na przykładzie rzeki Słupi, Ochr. Środ. 32, 2, 35-42.

15. Obolewski K., Glińska-Lewczuk K. 2006. Contents of heavy metals in bottom sediments of oxobow lakes and the Słupia River. Pol. J. Environ. Stud. 15, 2a, 440-444.

16. Ostrowska A., 1987. Application of ANE valueand shares of individual elements in this value for determining the difference between various plant species. Genetic aspects of plant mineral nutrition, 27 43, MartinusNijhoff Pub. (Plant and Soil). 
17. Ostrowska A., Gawliński S., Szczubiałka Z., 1991. Metody analizy i oceny właściwości gleb i roślin. Katalog,IOŚ, Warszawa.

18. Ostrowska A., Porębska G., 2002. Skład chemiczny roślin, jego interpretacja i wykorzystanie w ochronie środowiska. IOŚ, Warszawa.

19. Rabajczyk A., Jóźwiak M.A. 2009. Możliwości wykorzystania makrofitów jako bioindykatorów metali ciężkich zdeponowanych w osadach dennych, Monitoring Środowiska Przyrodniczego 9, 19-26.

20. Sadler P., 1998. Wetlands for mine water treatment Workshop. W: Constructed Wetlands Biofiltration. University of Wales, Cardiff.

21. Salati S., Moore F. 2009. Assessment of heavy metal concentration in the Khoshk River water and sediment, Shiraz, Southwest Iran. Environmental Monitoring and Assessment 164, 677-689.

22. Sarosiek J., Wożakowska-Natkaniec H. 1993. Chromi nikiel w roślinach $\mathrm{z}$ rodziny Lemnaceae i w ich środowisku. [W.] Chrom nikiel i glin - problemy ekologiczne i metodyczne. [red.] KabataPendias A., Z. PAN Kom. Człowiek i środowisko.

23. Sharma P., Asaeda T., Manatunge J., Fijino T., 2006. Nutrient cycling in a natural stand of Typhaangustifolia J. Freshwater Ecol. 21, 431.

24. Sasmaz A., Obek E., Hasar H. 2008. The accumulation of heavy metals in Typhalatifolia L. grown in a stream carrying secondary effluent. Ecol. Eng. $33,(3-4), 78$.

25. Skorbiłowicz E., 2003. Heavy metal content in bottom deposits and water plants in the Ełk River on urbanized area, Ecological Chemistry and Engineering 10, 9, 937-945.

26. Sobczyński T., Elbanowska H., Zerbe J., Siepak, J., 1996.Digestion of samples of bottom sediments prior to the determination of total contents of heavy metals. Gospodarka Wodna, 1996, 6, 570, pp. 173.

27. Teuchies J., Jacobs S., Oosterlee L., Bervoets L., Meire P., Role of plants in metal cycling in a wetland: Impications for phytoremediation. Science of Total Environment 445-446, 146-154.

28. Vardanyan L.G., Ingole B.S., 2006. Studies on heavy metal accumulation in aquatic macrophytes from Sevan (Armenia) and Carambolim (India) lake systems. Environ. Int. 32, 208-218.

29. Wilk M., Gworek B. 2009.Metale ciężkie w osadach ściekowych, Ochrona Środowiska i Zasobów Naturalnych 39, 40-59.

30. Wolska L., Mędrzycka K. 2009. Ocena ekotoksyczności osadów dennych $\mathrm{z}$ portów morskich W Gdańsku i Gdyni. Ochrona Środowiska 31, 1, 49-52.

31. Yang Y., Peterson E., Cambell C. 2001. Accumulation of heavy metals in urban soils and impacts on microorganism. Huan Jing KeXue 22, 3, 44-48. 